\title{
APPLICATIONS OF RADIOCARBON DATING METHOD
}

\author{
Irka Hajdas \\ Ion Beam Physics, ETH Zurich, Schafmattstr. 20, 8093 Zurich, Switzerland. Email: hajdas@phys.ethz.ch.
}

\begin{abstract}
The main force driving technical development of the radiocarbon dating technique is the wide spectrum of applications that cross interdisciplinary boundaries of Earth and social sciences. This paper provides a very brief overview of some of the many applications of ${ }^{14} \mathrm{C}$ analysis to various studies of human origin and migration, cultures and history, past and present environment, and the human body itself.
\end{abstract}

\section{INTRODUCTION}

From the early days of radiocarbon dating, 2 fields were clearly very interested in this method. Both archaeology and Earth sciences had their share in the establishment of ${ }^{14} \mathrm{C}$ dating. The first ${ }^{14} \mathrm{C}$ ages produced on archaeological and geological samples of "known age" illustrated the potential carried by the new method for these 2 research fields (Arnold and Libby 1949).

Wood samples from the Egyptian tombs of Zoser at Sakkara and Sneferu of Meydum were the very first archaeological objects ${ }^{14} \mathrm{C}$ dated (Libby et al. 1949) and were used to build the "Curve of Knowns." Sixty years ago, ${ }^{14} \mathrm{C}$ dating required several grams of material; therefore, very few precious objects could have been dated. Nevertheless, the number of dated samples grew rapidly (Polach 1980). ${ }^{14} \mathrm{C}$ ages revolutionized archaeology by providing a timescale that was independent of other studies (Libby 1980). At present, archaeology is the main ${ }^{14} \mathrm{C}$ application field, fostering close collaboration between archaeologists and ${ }^{14} \mathrm{C}$ specialists in various projects.

Quaternary geosciences studies are the second most important application of the ${ }^{14} \mathrm{C}$ dating method, and have supported the field from the very early days. Soon after publication of the first ${ }^{14} \mathrm{C}$ ages, new ${ }^{14} \mathrm{C}$ laboratories were established to measure the time observed in deposits studied across the world. Now, high-quality and high-resolution data are requested from ${ }^{14} \mathrm{C}$ labs. As with archaeology, Quaternary studies pace the development of the ${ }^{14} \mathrm{C}$ dating method.

The advent of the accelerator mass spectrometry (AMS) technique about $30 \mathrm{yr}$ ago is the best example of the interaction between these fields: the technical development pioneered by physicists was inspired by the need for solutions to problems such as dating of precious objects in archaeology (e.g. the Shroud of Turin). The ability to count the ${ }^{14} \mathrm{C}$ atoms remaining in the studied object instead of counting the decay rate revolutionized ${ }^{14} \mathrm{C}$ dating by downscaling the sample size required for age determination. In effect, new possibilities opened for dating unique objects. In response to this development, archaeology and Quaternary applications studies expanded, resulting in new problems to be addressed and solved. Moreover, new applications such as biomedical and environmental studies joined the spectrum of applications.

From this perspective, the last $60 \mathrm{yr}$ of ${ }^{14} \mathrm{C}$ dating applications appears as a continuous interdisciplinary dialogue supporting the development of the method and expansion of the fields of application.

\section{OVERVIEW OF SAMPLES TYPES SUBMITTED TO RADIOCARBON LABORATORIES}

Each of the applications of ${ }^{14} \mathrm{C}$ dating is characterized by the specific type of samples needed for ${ }^{14} \mathrm{C}$ dating. Figure 1 shows a breakdown of the most common materials submitted to the AMS ${ }^{14} \mathrm{C}$ laboratory at ETH, Zurich, during the last 15 yr. The most common samples are wood and charcoal, which are used by archaeology and Quaternary studies. The next group is bones, which are mainly

(C) 2009 by the Arizona Board of Regents on behalf of the University of Arizona Celebrating 50 Years of Radiocarbon

RADIOCARBON, Vol 51, Nr 1, 2009, p 79-90 
used in archaeology; however, some bone samples are used for Quaternary or forensic studies. The next largest group of samples is textiles, followed by foraminifera and mollusk shells, which are typically used in Quaternary studies. Sometimes mollusk shells are also used in archaeology, being the byproduct or rubbish/garbage found in remains of prehistoric human settlements. Quaternary studies and archaeology rely on ${ }^{14} \mathrm{C}$ ages obtained on terrestrial macrofossils, which are short-lived and free of reservoir age. Dating of the total organic carbon in the bulk sediments is often the only possible way to obtain the ${ }^{14} \mathrm{C}$ chronology for some lake sediments and decomposed peat. ${ }^{14} \mathrm{C}$ dating of various fractions of organic carbon in soil is also used to study the turnover time of the soils. Dissolved inorganic carbon in groundwater and ocean water is dated for environmental/paleoclimate studies or oceanography. A small portion of samples includes very specific materials that sometimes show up in the preparation line. These often address unusual questions that can be answered by ${ }^{14} \mathrm{C}$ measurements.

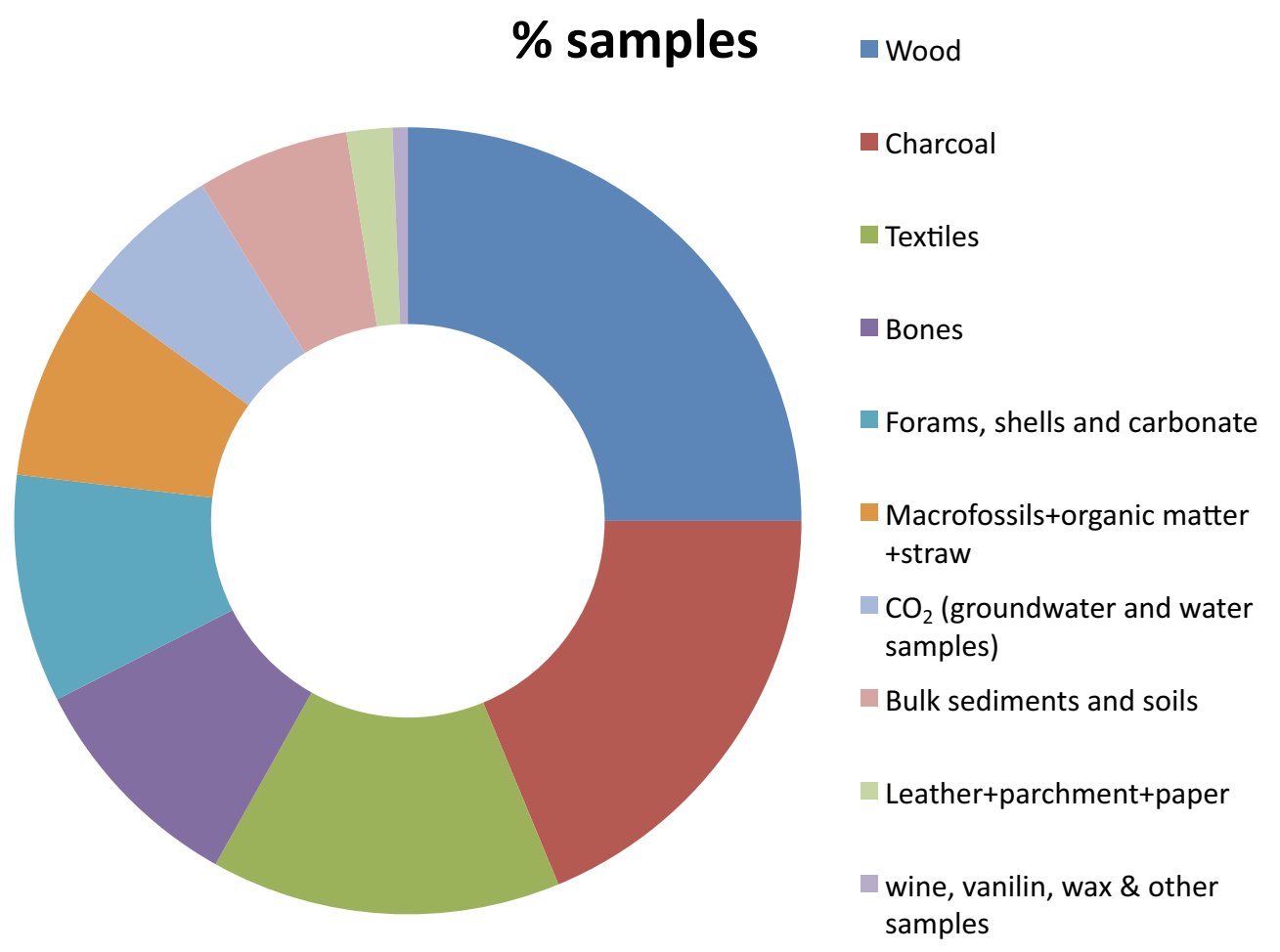

Figure 1 Breakdown of different samples types submitted to the ETH AMS ${ }^{14} \mathrm{C}$ dating laboratory during the last $15 \mathrm{yr}$

\section{OVERVIEW OF APPLICATIONS}

\section{Archaeology: Studies of Human History for the Last 50-60 kyr}

The most common samples submitted for ${ }^{14} \mathrm{C}$ dating are bones and charcoal. Less common are tissue and textile samples, hair and leather, which decompose quickly when in unfavorable conditions. Depending on the location of the archaeological sites, studies have their focus on different periods. For example, most of the ${ }^{14} \mathrm{C}$ ages obtained during the last $10 \mathrm{yr}$ for 1 archaeological institution in Switzerland are younger than $4000 \mathrm{BP}$; however, a small portion (16 samples out of 305) indicates the presence of sites dating between 5000 and 11,200 BP. 
Our example from Switzerland reflects the tendency in Europe, where most archaeological finds are younger than $10 \mathrm{kyr}$ BP. Nevertheless, ${ }^{14} \mathrm{C}$ ages are also obtained for the early Neolithic and Mesolithic. Nearly 800 charcoal samples recovered during extensive archaeological excavations accompanying the highway construction around Lake Neuchâtel, Switzerland, documented the whole spectrum of human occupational activities between 14,000 cal BP and the present (unpublished data, Archaeological Survey of Neuchâtel, Switzerland).

World archaeology might have different age distribution, and local patterns influence the distribution of ${ }^{14} \mathrm{C}$ ages of individual laboratories dependent on the projects. One international project in which ETH laboratory was involved was the construction of the chronology of Scythian burials at Pazyryk and Ulandryk in the Altai Mountains. The Scythian kurgans (tombs) found in the steppes of Eurasia reveal remains of the fascinating world left behind by nomadic people who were known for their love of horses and gold (Bachrach 1971). Despite the fact that organic matter was well preserved in the permafrost environment, precise dating of the kurgans posed a challenge. Due to the ${ }^{14} \mathrm{C}$ age plateau at $2500 \mathrm{BP}$, calibrated ages for most of the ${ }^{14} \mathrm{C}$ ages fall into the period between 700 and $300 \mathrm{BC}$. However, the trunks of larch used for building the tombs were perfectly preserved, which allowed dendrochronology to be applied. The combination of ${ }^{14} \mathrm{C}$ dating and the tree-ring chronology enables overcoming problems caused by the tentative tree-ring master curve of this region. A sequence of ages obtained for a tree was placed on the calibration curve, which set the calendar age of the last ring in the range between 296 and 330 BC (Figure 2) (Hajdas et al. 2004).

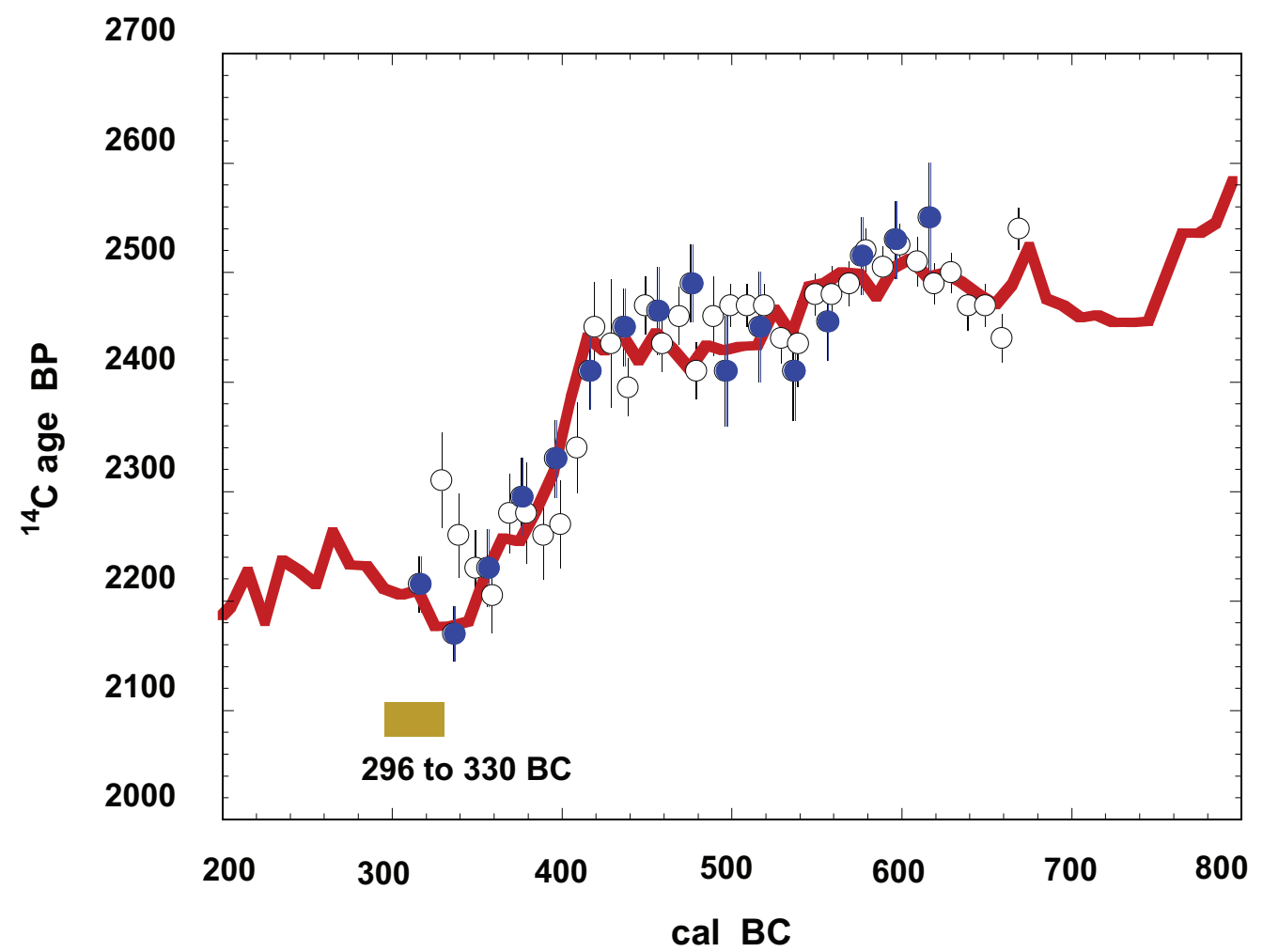

Figure $2{ }^{14} \mathrm{C}$ dating of a larch $\log$ from the Ulandryk kurgan. The closed circles are ${ }^{14} \mathrm{C}$ ages obtained by Hajdas et al. (2004); the open circles are data from Slusarenko et al. (2002). Modified from Hajdas et al. (2004). 
Late Paleolithic sites across Europe and Eurasia contain mostly charcoal or bones, which are suitable for dating. The limit of the ${ }^{14} \mathrm{C}$ dating method at around $50 \mathrm{kyr}$ still allows for ${ }^{14} \mathrm{C}$ dating of the Middle to Upper Paleolithic transition and the first appearance of anatomically modern humans in Europe as well as remains of the last Neanderthals (Conard and Bolus 2003; Conard 2006). Answering the questions of coexistence of these 2 species relies on accurate chronologies of this time interval. Some of the ${ }^{14} \mathrm{C}$ ages reported thus far suggest that Neanderthals survived into to the period 30 $40 \mathrm{kyr}$ BP, thus documenting the presence of anatomically modern humans (for discussion, see Klein 2003). At present, this is one of the challenges faced by ${ }^{14} \mathrm{C}$ dating, because in this time window calibration problems add to the problem of ${ }^{14} \mathrm{C}$ dating at the limit of the method.

\section{Quaternary Studies and Climate Change}

The last 50 kyr in Earth history includes the last glacial cycle and 11,000 yr of Holocene warm climate. The changes of climate experienced by the Earth left clear imprints on the landscape. ${ }^{14} \mathrm{C}$ dating of these natural archives provides the time frame for climatic fluctuations. Lake sediments are usually dated using terrestrial macrofossils, which are free of the "hard water" effect, i.e. old carbon present in lake water. Total organic carbon is used when the lake is considered to be free of dissolved old carbonates washed in from the catchment area.

Deep-sea cores are dated using ${ }^{14} \mathrm{C}$ ages of foraminifera shells. This application only became possible with the advent of the AMS measurement technique, which replaced dating of bulk carbonate by decay counting. The periods of interest within the limit of the ${ }^{14} \mathrm{C}$ dating method include oxygen isotope stage 3, last glacial maximum (LGM), last deglaciation, and the Holocene. From its early days, ${ }^{14} \mathrm{C}$ dating provided the first numerical ages for the boundaries of these periods. Detection of millennial timescale fluctuations, the so-called Daansgaard-Oeschger (DO) events, in Greenland ice cores (Dansgaard et al. 1993) prompted more detailed investigations of continental and marine records. Moreover, higher resolution is required for observation and correlation of abrupt climatic events. Leads and lags between changes observed at different sites could only be resolved with good chronological time frames. These are essential for understanding the mechanisms that caused the particular events. For example, the timing for the beginning of the Younger Dryas, i.e. the last cold spell of the Late Glacial observed around 11 and $10 \mathrm{kyr}$ BP in European lakes and peat bogs, was established using ${ }^{14} \mathrm{C}$ dating (Mangerud et al. 1974). Many sites around the world have shown Younger Dryas-type cooling at the end of the Late Glacial with ${ }^{14} \mathrm{C}$ ages close to $11 \mathrm{kyr} \mathrm{BP}$ (for a review, see Peteet 1995). However, it has also been shown with the help of ${ }^{14} \mathrm{C}$ dating that the timing of the Younger Dryas as observed in terrestrial and marine records of the North Atlantic region is different from the cold reversals at some locations from the Southern Hemisphere (Patagonia and New Zealand; Hajdas et al. 2003, 2006).

The early 1990s brought attention to another type of climatic event that was first observed in marine cores recovered from the North Atlantic. Layers of ice-rafted debris (IRD) are found in sediment cores of the North Atlantic, documenting paths of the iceberg fleets floating southwards (Heinrich 1988; Bond et al. 1992). Chronologies of these cold Heinrich events (HE) are based on ${ }^{14} \mathrm{C}$ dating of foraminifera shells found in those layers or in sediments bracketing them. Four of the HE occurred during the last $45 \mathrm{kyr}$ and can be ${ }^{14} \mathrm{C}$ dated. Correlation of globally distributed sites that record the impact of HEs is quite often based on ${ }^{14} \mathrm{C}$ chronologies (Broecker and Hemming 2001; Hemming 2004).

Reliable ${ }^{14} \mathrm{C}$ ages are essential for the approaches listed above, especially when the ages are close to the limit of the method. Removal of contamination is one of the problems addressed by ${ }^{14} \mathrm{C}$ laboratories. For example, ${ }^{14} \mathrm{C}$ dating of a mammoth find from Niederweningen was performed on mam- 
moth tusk and bones as well as on peat and wood from the section in which the mammoth was found (Figure 3). The precleaned gelatin fraction, which was treated with base (Arslanov and Svezhentsev 1993) and/or ultrafiltration (Brown et al. 1988), yielded a consistent ${ }^{14} \mathrm{C}$ age of $45,720 \pm 710 \mathrm{BP}$ (Hajdas et al. 2007, 2009). The same age was obtained on a sample taken from the top of the mammoth peat layer (Figure 3). The coherent ${ }^{14} \mathrm{C}$ ages suggest the effectiveness of the applied treatments.

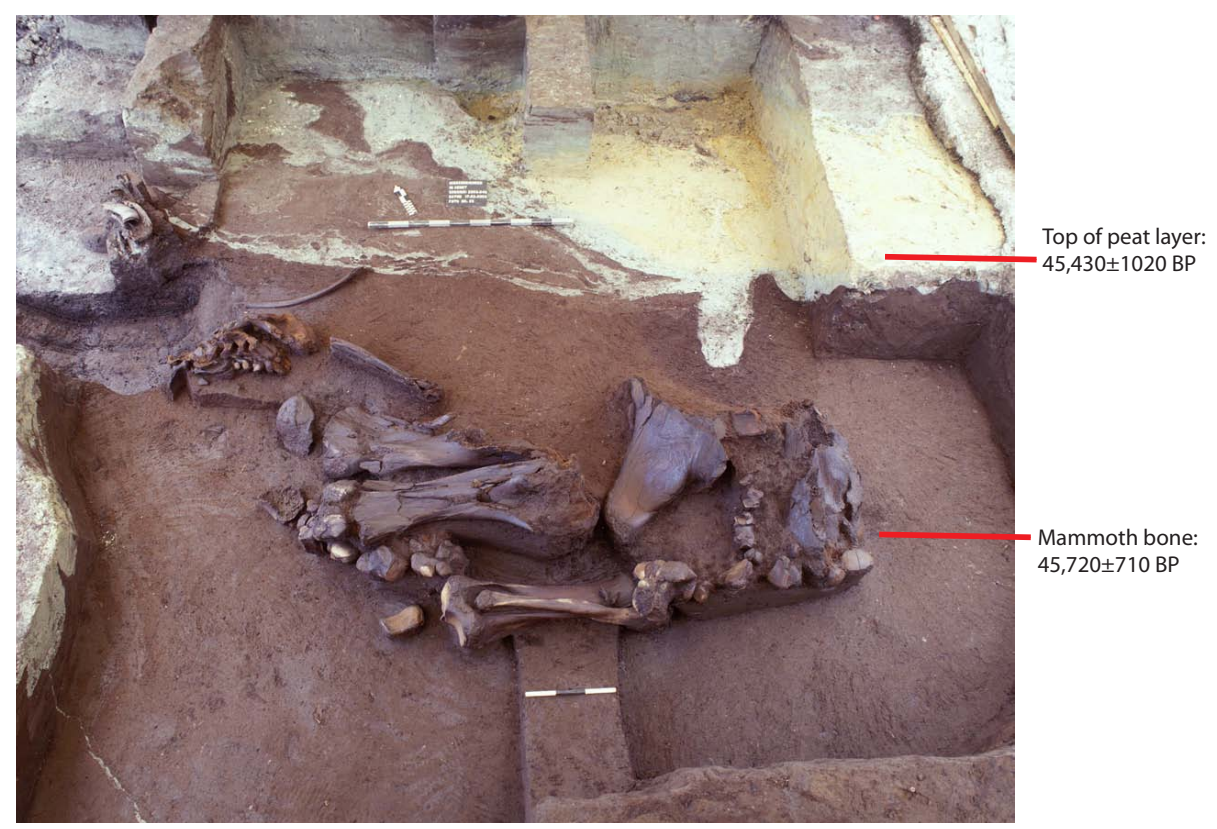

Figure $3{ }^{14} \mathrm{C}$ chronology of a mammoth find in Niederweningen, Switzerland (Hajdas et al. 2007, 2009)

Another archive of past climate changes is groundwater. Stable isotopes $\left(\delta \mathrm{D}, \delta^{13} \mathrm{C}, \delta^{18} \mathrm{O}\right)$ and noble gases $(\mathrm{Ar}, \mathrm{Kr}, \mathrm{Ne}, \mathrm{Xe})$ in groundwater record the temperature of the air at the time of recharge. This last encounter and exchange of gases with the atmosphere can be traced back by ${ }^{14} \mathrm{C}$ dating of dissolved inorganic carbon, DIC (i.e. $\mathrm{CO}_{2}, \mathrm{HCO}^{3-}, \mathrm{CO}^{3-}$ ). Studies of the paleo-aquifer around the world show that during the LGM temperatures were lower by $3-5{ }^{\circ} \mathrm{C}$ even at low latitudes (Stute et al. 1995a,b). Figure 4 shows the noble gas temperature reconstructions in the Sahel region (Beyerle et al. 2003). The gap in the record observed between 23 and $15 \mathrm{kyr}$ BP indicates reduced groundwater recharge during the arid LGM.

\section{The Oceans-Present and Past}

Most of the ${ }^{14} \mathrm{C}$ produced in the atmosphere ends up entering the ocean, which is the largest carbon reservoir. $\mathrm{CO}_{2}$ exchange rates are based on tracking the dissolved $\mathrm{CO}_{2}$ that reflect "bomb peak" ${ }^{14} \mathrm{C}$, i.e. the excess of ${ }^{14} \mathrm{C}$ produced artificially during the $1950 \mathrm{~s} / 60$ s nuclear tests. Mapping the distribution of natural ${ }^{14} \mathrm{C}$ and bomb ${ }^{14} \mathrm{C}$ allows reconstruction of the ocean circulation. In the GEOSECS project (1972-78), samples of water were collected from ships crossing the oceans and analyzed for ${ }^{14} \mathrm{C}$ content. In the early days, when the conventional technique required grams of carbon, 200-L water samples had been collected. These numerous measurements allowed reconstruction of the regions with sinking water masses (deep-water produced) and the upwelling regions where "old" waters come to the surface (Broecker et al. 1978, 1985). 


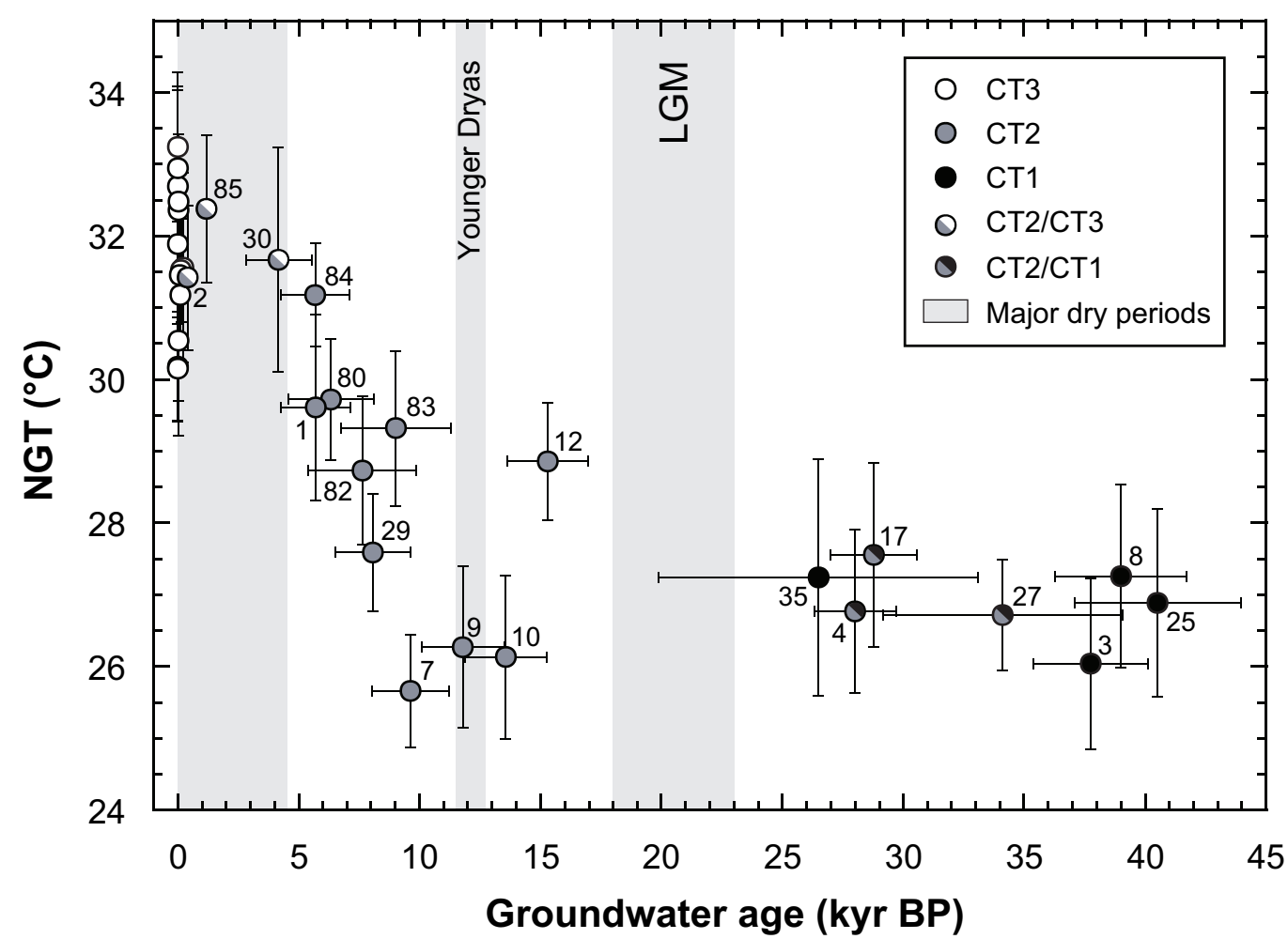

Figure 4 Calibrated ${ }^{14} \mathrm{C}$ ages of groundwater provide a timescale for temperature changes (nobel gas temperature [NGT]) in the Sahel region (Figure 2 from Beyerle et al. 2003). Reprinted with permission.

The pathways of water masses can be traced by ${ }^{14} \mathrm{C}$ dating of fossils in the deep-sea sediments. Shells of plankton foraminifera register the ${ }^{14} \mathrm{C}$ signature of the mixed-layer waters, whereas calcite of the benthic zooplankton reflects the ${ }^{14} \mathrm{C}$ content of the bottom water (i.e. its ${ }^{14} \mathrm{C}$ age). Paleoreservoir ages are only partially known at present. However, even this limited picture suggests significant fluctuations occurred in the past (Bondevik et al. 2006).

\section{${ }^{14} \mathrm{C}$ Dating and Environmental Studies}

Anthropogenic changes in the atmospheric ${ }^{14} \mathrm{C}$ content caused by fossil fuel combustion and the addition of " ${ }^{14} \mathrm{C}$-free" carbon (Suess effect), as well as the nuclear tests $\left({ }^{14} \mathrm{C}\right.$ bomb peak), greatly affected the ${ }^{14} \mathrm{C}$ dating of the last $150 \mathrm{yr}$. Measurements of the atmospheric ${ }^{14} \mathrm{C}$ content have been performed during the last $50 \mathrm{yr}$ (Hua and Barbetti 2004; Levin and Kromer 2004). Stations located around the world collect air samples from pristine and urban areas. While the bomb ${ }^{14} \mathrm{C}$, which is a very useful tracer for environmental studies (Levin and Hesshaimer 2000), is leveling off mainly due to the ocean uptake, the fossil fuel impact is observed especially in the urban regions (Levin et al. 2008). One of the recent applications of ${ }^{14} \mathrm{C}$ analysis is monitoring biogenic fuel for clandestine additions of fossil fuel.

Studies of sources of carbonaceous particles (aerosols) in the atmosphere use ${ }^{14} \mathrm{C}$ analysis to determine portions of the OC (organic carbon, modern) and EC (elemental carbon, fossil fuels) (Currie et al. 1997). Other environmental studies make use of bomb ${ }^{14} \mathrm{C}$. For example, estimation of the turnover time of soils is possible with the help of ${ }^{14} \mathrm{C}$ measurements made on various fractions 
(pools) of soil organic matter SOM. In a study of Sierra Nevada soils, Trumbore et al. (1996) measured ${ }^{14} \mathrm{C}$ content of transects of pre- and post-1963 soils. The results showed that fractions with different density have different turnover time. The low-density fraction $\left(<2 \mathrm{~g} / \mathrm{cm}^{3}\right)$ is the fastest of the $\mathrm{SOM}$, showing a quick response to the bomb ${ }^{14} \mathrm{C}$ signal and high ${ }^{14} \mathrm{C}$ content for pre-bomb soils. The hydrolyzable high-density fraction $\left(>2.0 \mathrm{~g} / \mathrm{cm}^{3}\right)$ is the intermediate portion reacting slower than the low-density fraction. The slowest pool is made up of high-density nonhydrolyzable $\left(>2.0 \mathrm{~g} / \mathrm{cm}^{3}\right)$ portions of SOM, which showed the lowest pre-bomb ${ }^{14} \mathrm{C}$ concentrations and lowest impact of bomb ${ }^{14} \mathrm{C}$ (Figure 5).
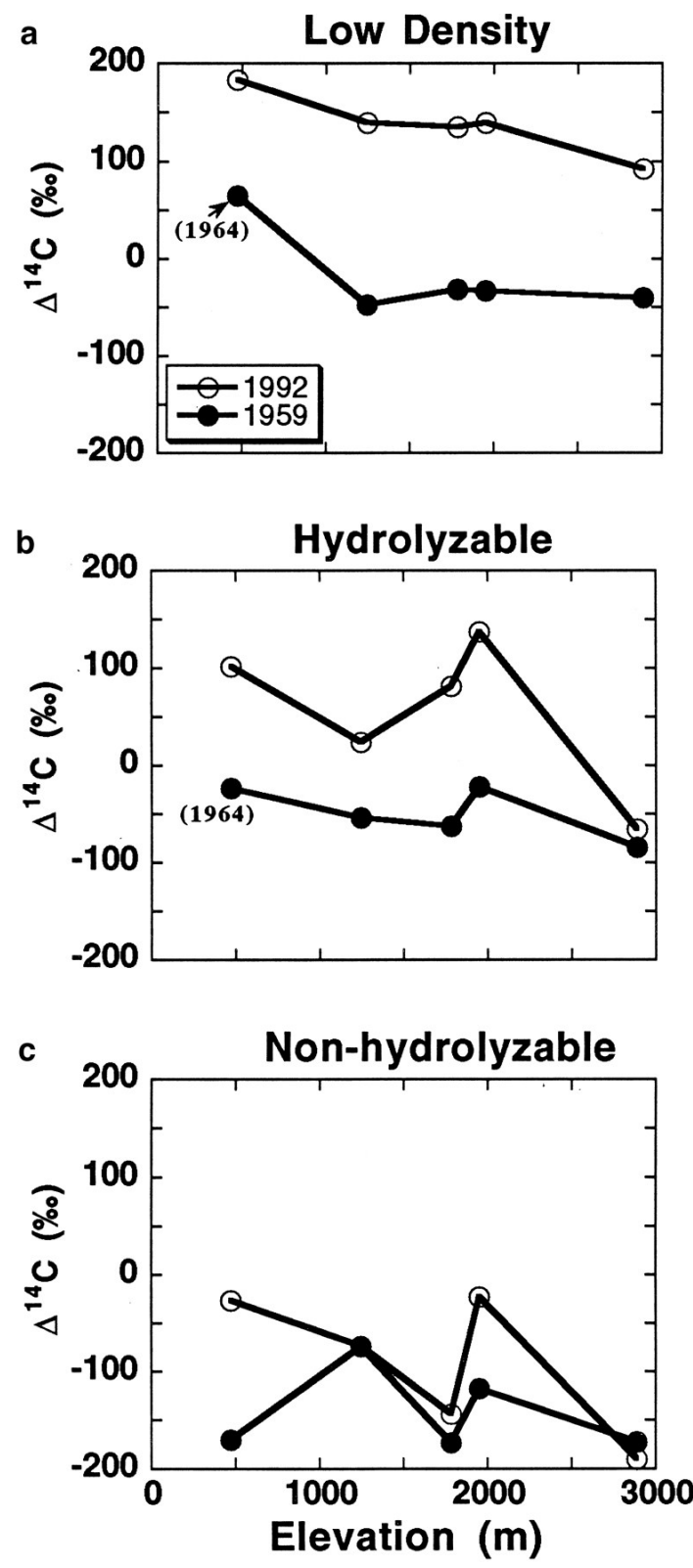

Figure 5 Changes in ${ }^{14} \mathrm{C}$ content of different fractions of soils collected between 1959 and 1992 on Sierra Nevada slopes (Figure 3 from Trumbore 1997). Reprinted with permission. 


\section{Compound-Specific Radiocarbon Analysis (CSRA)}

Thanks to a technical development allowing ${ }^{14} \mathrm{C}$ analysis of samples containing micrograms of carbon, ${ }^{14} \mathrm{C}$ analysis at the molecular level became possible (Currie et al. 1985). Ingalls and Pearson (2005) gave an overview of the applications developed in the first decade of CSRA. Chromatographic separation and ${ }^{14} \mathrm{C}$ dating of individual biomarkers from deep-sea sediments provide information about sources of various components as well as the processes of organic carbon transport, degradation, and burial. A similar approach can be applied to the determination of various components of soils (Rethemeyer et al. 2004). Moreover, attempts are being made to use CSRA to date paleoproxy records. One of the great dreams of researchers working with sediment cores from the Southern Ocean, where hardly any foraminifera can be found, is obtaining ${ }^{14} \mathrm{C}$ chronologies of their records (Zheng et al. 2002). Ingalls et al. (2004) proposed CSRA of diatom frustules, which could help to bypass the lack of foraminifera. Another application of CSRA, tested more than a decade ago but not fully exploited yet, is dating bone specific amino acids to avoid intrusive carbon that might alter the ${ }^{14} \mathrm{C}$ age of the bone (Van Klinken et al. 1994).

\section{Biomedical}

The subject of ${ }^{14} \mathrm{C}$ in the human body has been studied already in the early years of ${ }^{14} \mathrm{C}$ dating. The sudden appearance of the bomb peak provided an excellent tracer, which allowed estimation of the turnover time of carbon in the human body (Broecker et al. 1959; Libby et al. 1964; Nydal et al. 1971). Except for bone collagen, most body organs have a short turnover time and are close to the contemporary levels of atmospheric ${ }^{14} \mathrm{C}$. Moreover, the dietary effect (such as the impact of seafood on ${ }^{14} \mathrm{C}$ content) has been established, which is of great use for ${ }^{14} \mathrm{C}$ dating in archaeological studies (Harkness and Walton 1972).

Because of the small amount of carbon required (down to $2.5 \mu \mathrm{g}$; Ruff et al. 2007), dating of specific cell types and molecules is now possible. A clinical study by Robertson et al. (2001) determined the formation of senile plaques (SP) and neurofibrillary tangles (NFT). Two characteristic features are observed in the human brain affected by Alzheimer's disease. The study aimed to establish the chronological relation between the formation of NFT and SP and the onset of Alzheimer's symptoms. Results suggested that in most cases NFT and SP started to accumulate after the first symptoms were observed.

The existence of the bomb ${ }^{14} \mathrm{C}$ spike provides a marker for the generation born in the late $1950 \mathrm{~s}$ and later. As the bomb peak is leveling off, such studies might become less applicable to later generations. Spalding et al. (2005a) applied AMS ${ }^{14} \mathrm{C}$ dating of genomic DNA, which retains its original carbon without exchange. Dating of the formation time of the cells in the various regions of the human brain can help answer questions of possible neurogenesis. The ${ }^{14} \mathrm{C}$ concentration in genomic DNA of the cortex neurons indicated its formation at birth with little indication of later formation of the neurons (Spalding et al. 2005a).

\section{Forensic}

Determination of the time of death of an organism is the direct information of ${ }^{14} \mathrm{C}$ dating and is applied in forensic investigations. ${ }^{14} \mathrm{C}$ dating of a glacier mummy found in the Alps in 1991 is a popular example of dating discovered human remains. The archaeological context found with Ötzi (named after the Ötztal Alps where it was found) indicated that the body was not from the last decades; instead, it was dated to $4546 \pm 17$ BP, i.e. 3350-3110 BC (Bonani et al. 1994). However, in some cases such a context is missing or the time window must be estimated more precisely. Bomb ${ }^{14} \mathrm{C}$ dating is a useful tool for the last $60 \mathrm{yr}$ for it allows pinpointing the time of death (Wild et al. 
2000; Tuniz et al. 2004). It has also been proposed to use ${ }^{14} \mathrm{C}$ dating of tooth enamel to help estimate the time when the tooth was formed, and therefore the year of the birth (Spalding et al. 2005b).

\section{Art History, Textiles, and Fraud Detection}

Art objects have been found in Middle Paleolithic layers, mostly made of bone, antler, or ivory, which are robust material and can be ${ }^{14} \mathrm{C}$ dated. Typically, however, the pieces are so precious that their dating is performed on associated material, i.e. bone or charcoal found in the same layer. In some cases, the AMS technique allowed direct dating of unique objects such as the prehistoric paintings from Chauvet Cave (France), which were created between 29,700 and 32,900 BP (Clottes et al. 1995).

An overview of the history of textiles is given by Barber (1992). The first indication of weaving was found for the early Neolithic. Impressions of textiles discovered in Jarmo, Iraq, might be as old as $7000 \mathrm{BC}$, and a linen cloth created around $6500 \mathrm{BC}$ was found in a dry cave in Nahal Hemal, Israel. In the 1960s, fragments of textiles were recovered from the Anatolian prehistoric town of Çatal Höyük that dated back to 6000 BC. The first woven textiles in Egypt appeared around 5000 BC. Linen textiles from Swiss Neolithic sites date to around 3000 BC. However, most of these objects are not directly ${ }^{14} \mathrm{C}$ dated because their discoveries were made before or in the early days of the ${ }^{14} \mathrm{C}$ dating method.

Following the dating of the Shroud of Turin (Damon et al. 1989), ${ }^{14} \mathrm{C}$ dating of unique textiles became reality. Van Strydonck et al. (2004) compared ${ }^{14} \mathrm{C}$ ages of Roman and Coptic textiles with their art historical dating, showing that the methods provide similar precision. Often discussed are the "frustrations" caused by the existence of wiggles in the final $400 \mathrm{yr}$ of the calibration curve. Many art objects and textiles date to this time period; consequently, their calibrated ages represent wide ranges of calendar ages, but additional information (historic notes, ownership record, style, pigment) can help to narrow the range. For example, the ${ }^{14} \mathrm{C}$ age of the oldest knotted pile rug found in Kurgan V of Pazyryk is $2245 \pm 35$ BP (Rageth 1999) and falls in the region of the age plateau at 2200 BP. However, with the help of chronologies built for Kurgan II and other kurgans of the Pazyryk culture, as described above, the calendar age of this textile can be placed between 383 and 238 BC (Hajdas et al. 2004).

Art forgery creates and/or sells works that imitate original pieces of art. There are objects that are attributed to famous artists but also antique objects that are highly prized because of their age. In some cases, ${ }^{14} \mathrm{C}$ dating is able to detect false material by measurement of the ${ }^{14} \mathrm{C}$ content of the material used. Most cases are straightforward and forgery is detected as post-AD 1950 products. But some pieces are created on old materials in order to bypass the bomb peak signature. Such attempts indicate that there is a common awareness of the potentials that ${ }^{14} \mathrm{C}$ dating has for the detection of forgery. However, the ability to acquire material of the desired age in order to produce sophisticated forgery is rather limited.

Recent (post-AD 1950) attempts to imitate ancient textiles can also be detected. Nearly $1 \%$ of all the textiles dated at the ETH laboratory appear to be post-AD 1950 or modern, i.e. containing bomb ${ }^{14} \mathrm{C}$. The forgeries that predate the bomb peak are less obvious and their detection requires expertise in other parameters such as pigments, styles, etc. Moreover, a possibility of mixing or fabricating material to obtain the desired ${ }^{14} \mathrm{C}$ age cannot be excluded, as reported by Nadeau et al. (2008). 


\section{SUMMARY}

As foreseen in the early days of the method, ${ }^{14} \mathrm{C}$ dating can be used in a wide spectrum of applications in various fields. The methodological and measurement developments that happened during the last 6 decades were only possible because of interdisciplinary collaboration. Also, the future of ${ }^{14} \mathrm{C}$ applications relies on communication between laboratories and the users. The growing number of laboratories allows much shorter turnaround time for ${ }^{14} \mathrm{C}$ ages and much higher throughput. Thus, high-resolution chronologies are becoming a common practice. Environmental and biomedical studies are increasing the sample load, and the dynamic field of CSRA is adding new applications and giving new opportunities of tracking contamination in samples.

\section{REFERENCES}

Arnold JR, Libby WF. 1949. Age determinations by radiocarbon content: checks with samples of known age. Science 110(2869):678-80.

Arslanov KA, Svezhentsev YS. 1993. An improved method for radiocarbon dating fossil bones. Radiocarbon 35(3):387-91.

Bachrach BS. 1971. Frozen tombs of Siberia: the Pazyryk burials of Iron Age horsemen. American Historical Review 76(3):754.

Barber EJW. 1992. Prehistoric Textiles: The Development of Cloth in the Neolithic and Bronze Ages with Special Reference to the Aegean. Princeton: Princeton University Press. 508 p.

Beyerle U, Rueedi J, Leuenberger M, Aeschbach-Hertig W, Peeters F, Kipfer R, Dodo A. 2003. Evidence for periods of wetter and cooler climate in the Sahel between 6 and $40 \mathrm{kyr}$ BP derived from groundwater. Geophysical Research Letters 30(4):1173, doi: 10.1029/2002GL016310.

Bonani G, Ivy SD, Hajdas I, Niklaus TR, Suter M. 1994. AMS ${ }^{14} \mathrm{C}$ age determinations of tissue, bone and grass samples from the Ötztal Ice Man. Radiocarbon 36(2): 247-50.

Bond G, Heinrich H, Broecker W, Labeyrie L, McManus J, Andrews J, Huon S, Jantschik R, Clasen S, Simet C, Tedesco K, Klas M, Bonani G, Ivy S. 1992. Evidence for massive discharges of icebergs into the North Atlantic Ocean during the Last Glacial period. Nature 360(6401):245-9.

Bondevik S, Mangerud J, Birks HH, Gulliksen S, Reimer P. 2006. Changes in North Atlantic radiocarbon reservoir ages during the Allerød and Younger Dryas. Science 312(5779):1514-7.

Broecker WS, Hemming S. 2001. Climate swings come into focus. Science 294(5550):2308-9.

Broecker WS, Schulert A, Olson EA. 1959. Bomb carbon-14 in human beings. Science 130(3371):331-2.

Broecker WS, Peng T-H, Stuiver M. 1978. An estimate of the upwelling rate in the equatorial Atlantic based on the distribution of bomb radiocarbon. Journal of Geophysical Research 83(C12):6179-86.

Broecker WS, Peng T-H, Ostlund G, Stuiver M. 1985.
The distribution of bomb radiocarbon in the ocean. Journal of Geophysical Research 90(C4):6953-70.

Brown TA, Nelson DE, Vogel JS, Southon JR. 1988. Improved collagen extraction by modified Longin method. Radiocarbon 30(2):171-7.

Clottes J, Chauvet JM, Bruneldeschamps E, Hillaire C, Daugas JP, Arnold M, Cachier H, Evin J, Fortin P, Oberlin C, Tisnerat N, Valladas H. 1995. The Paleolithic paintings of the Chauvet-Pont-d'Arc Cave, at Vallon-Pont-d'Arc (Ardeche, France): direct and indirect radiocarbon datings. Comptes Rendus de l'Academie des Sciences Serie II 320(11):1133-40.

Conard NJ. 2006. When Neanderthals and Modern Humans Met. Tuebingen: Kerns Verlag. 501 p.

Conard NJ, Bolus M. 2003. Radiocarbon dating and the appearance of modern humans and timing of cultural innovations in Europe: new results and new challenges. Journal of Human Evolution 44(3):331-71.

Currie LA, Klouda GA, Elmore D, Gove HE. 1985. Radiocarbon dating of microgram samples: accelerator mass spectrometry and electromagnetic isotope separation. Nuclear Instruments and Methods in Physics Research B 12(3):396-401.

Currie LA, Eglinton TI, Benner BA, Pearson A. 1997. Radiocarbon "dating" of individual chemical compounds in atmospheric aerosol: first results comparing direct isotopic and multivariate statistical apportionment of specific polycyclic aromatic hydrocarbons. Nuclear Instruments and Methods in Physics Research B 123(1-4):475-86.

Damon PE, Donahue DJ, Gore BH, Hatheway AL, Jull AJT, Linick TW, Sercel PJ, Toolin LJ, Bronk CR, Hall ET, Hedges REM, Housley R, Law IA, Perry C, Bonani G, Trumbore S, Woelfli W, Ambers JC, Bowman SGE, Leese MN, Tite MS. 1989. Radiocarbon dating of the Shroud of Turin. Nature 337(6208):611-5.

Dansgaard W, Johnsen SJ, Clausen HB, Dahl-Jensen D, Gundestrup NS, Hammer CU, Hvidberg CS, Steffensen JP, Sveinbjörnsdóttir AE, Jouzel J, Bond G. 1993. Evidence for general instability of past climate from a 250-kyr ice-core record. Nature 364(6434): 218-20. 
Hajdas I, Bonani G, Moreno PI, Ariztegui D. 2003. Precise radiocarbon dating of late-glacial cooling in midlatitude South America. Quaternary Research 59(1): 70-8.

Hajdas I, Bonani G, Slusarenko IY, Seifert M. 2004. Chronology of Pazyryk 2 and Ulandryk 4 kurgans based on high resolution radiocarbon dating and dendrochronology - a step towards precise dating of Scythian burials. In: Scott EM, Alekseev AY, Zaitseva G, editors. Impact of the Environment on the Human Migration in Eurasia. Dordrecht: Kluwer Academic Publishers. p 107-16.

Hajdas I, Lowe DJ, Newnham RM, Bonani G. 2006. Timing of the late-glacial climate reversal in the Southern Hemisphere using high-resolution radiocarbon chronology for Kaipo bog, New Zealand. Quaternary Research 65(2):340-5.

Hajdas I, Bonani G, Furrer H, Mäder A, Schoch W. 2007. Radiocarbon chronology of the mammoth site at Niederweningen, Switzerland: results from dating bones, teeth, wood, and peat. Quaternary International 164-165:98-105.

Hajdas I, Michczyński A, Bonani G, Wacker L, Furrer H. 2009. Dating bones near the time limit of radiocarbon dating method: study case mammoth from Niederweningen, Switzerland. Radiocarbon 51(2).

Harkness DD, Walton A. 1972. Further investigations of transfer of bomb ${ }^{14} \mathrm{C}$ to man. Nature 240(5379):3023.

Heinrich H. 1988. Origin and consequences of cyclic ice rafting in the northeast Atlantic Ocean during the past 130,000 years. Quaternary Research 29(2):142-52.

Hemming SR. 2004. Heinrich events: massive late Pleistocene detritus layers of the North Atlantic and their global climate imprint. Reviews of Geophysics 42: RG1005, doi:10.1029/2003RG000128.

Hua Q, Barbetti M. 2004. Review of tropospheric bomb ${ }^{14} \mathrm{C}$ data for carbon cycle modeling and age calibration purposes. Radiocarbon 46(3):1273-98.

Ingalls AE, Pearson A. 2005. Ten years of compoundspecific radiocarbon analysis. Oceanography 18(3): $18-31$.

Ingalls AE, Anderson RF, Pearson A. 2004. Radiocarbon dating of diatom-bound organic compounds. Marine Chemistry 92(1-4):91-105.

Klein RG. 2003. Whither the Neanderthals? Science 299(5612):1525-7.

Levin I, Hesshaimer V. 2000. Radiocarbon-a unique tracer of global carbon cycle dynamics. Radiocarbon 42(1):69-80.

Levin I, Kromer B. 2004. The tropospheric ${ }^{14} \mathrm{CO}_{2}$ level in mid-latitudes of the Northern Hemisphere (19592003). Radiocarbon 46(3):1261-72.

Levin I, Hammer S, Kromer B, Meinhardt F. 2008. Radiocarbon observations in atmospheric $\mathrm{CO}_{2}$ : determining fossil fuel $\mathrm{CO}_{2}$ over Europe using Jungfraujoch observations as background. Science of the Total Environment 391(2-3):211-6.
Libby WF. 1980. Archaeology and radiocarbon dating. Radiocarbon 22(4):1017-20.

Libby WF, Anderson EC, Arnold JR. 1949. Age determination by radiocarbon content: world-wide assay of natural radiocarbon. Science 109(2827):227-8.

Libby WF, Berger R, Mead JF, Alexander GV, Ross JF. 1964. Replacement rates for human tissue from atmospheric radiocarbon. Science 146(3648):1170-2.

Mangerud J, Andersen ST, Berglund BE, Donner JJ. 1974. Quaternary stratigraphy of Norden, a proposal for terminology and classification. Boreas 3(3):10926.

Nadeau M-J, Huls CM, Grootes PM. 2008. Attention fraud: modern fabrics made to date old [poster 6.14]. Radiocarbon and Archaeology 5th International Symposium, 26-28 March 2008. Zurich, Switzerland.

Nydal R, Lövseth K, Syrstad O. 1971. Bomb ${ }^{14} \mathrm{C}$ in the human population. Nature 232(5310):418-21.

Peteet D. 1995. Global Younger Dryas? Quaternary International 28:93-104.

Polach D. 1980. The first 20 years of radiocarbon dating. An annotated bibliography, 1948-68; a pilot study. Radiocarbon 22(3):997-1004.

Rageth J. 1999. Anatolian Kilims and Radiocarbon Dating. Basel: Rageth \& Freunde des Orienttepiche.

Rethemeyer J, Kramer C, Gleixner G, Wiesenberg GLB, Schwark L, Andersen N, Nadeau M-J, Grootes PM. 2004. Complexity of soil organic matter: AMS ${ }^{14} \mathrm{C}$ analysis of soil lipid fractions and individual compounds. Radiocarbon 46(1):465-73.

Robertson JD, Lovell MA, Buchholz B, Xie CS, Markesbery WR. 2001. Use of bomb pulse ${ }^{14} \mathrm{C}$ to age senile plaques and neurofibrillary tangles in the Alzheimer's disease brain. Journal of Radioanalytical and Nuclear Chemistry 249(2):443-7.

Ruff M, Wacker L, Gäggeler HW, Suter M, Synal H-A, Szidat S. 2007. A gas ion source for radiocarbon measurements at $200 \mathrm{kV}$. Radiocarbon 49(2):307-14.

Slusarenko I, Kuzmin YV, Christen JA, Burr GS, Jull AJT, Orlova LA. 2002. ${ }^{14} \mathrm{C}$ wiggle-matching of the Ulandryk-4 (Early Iron Age, Pazyryk cultural complex) floating tree-ring chronology, Altai Mountains, Siberia. In: Higham T, Bronk Ramsey C, Owen C, editors. Radiocarbon and Archaeology: Fourth International Symposium. Oxford, 9-14 April 2002. Oxford: Oxbow Books. p 177-84.

Spalding KL, Bhardwaj RD, Buchholz BA, Druid H, Frisén J. 2005a. Retrospective birth dating of cells in humans. Cell 122(1):133-43.

Spalding KL, Buchholz BA, Bergman L-E, Druid H, Frisén J. 2005b. Age written in teeth by nuclear tests. Nature 437(7057):333-4.

Stute M, Clark JF, Schlosser P, Broecker WS, Bonani G. 1995a. A 30,000 yr continental paleotemperature record derived from noble gases dissolved in groundwater from the San Juan Basin, New Mexico. Quaternary Research 43(2):209-20.

Stute M, Forster M, Frischkorn H, Serejo A, Clark JF, 
Schlosser P, Broecker WS, Bonani G. 1995b. Cooling of tropical Brazil $\left(5^{\circ} \mathrm{C}\right)$ during the Last Glacial Maximum. Science 269(5222):379-83.

Trumbore SE. 1997. Potential responses of soil organic carbon to global environmental change. Proceedings of the National Academy of Sciences of the United States of America 94(16):8284-91.

Trumbore SE, Chadwick OA, Amundson R. 1996. Rapid exchange between soil carbon and atmospheric carbon dioxide driven by temperature change. Science 272(5260):393-6.

Tuniz C, Zoppi U, Hotchkis MAC. 2004. Sherlock Holmes counts the atoms. Nuclear Instruments and Methods in Physics Research B 213:469-75.

Van Klinken GJ, Bowles AD, Hedges REM. 1994. Radiocarbon dating of peptides isolated from contami- nated fossil bone collagen by collagenase digestion and reversed-phase chromatography. Geochimica et Cosmochimica Acta 58(11):2543-51.

Van Strydonck M, De Moor A, Bénazeth D. 2004. ${ }^{14} \mathrm{C}$ dating compared to art historical dating of Roman and Coptic textiles from Egypt. Radiocarbon 46(1):23144.

Wild EM, Arlamovsky KA, Golser R, Kutschera W, Priller A, Puchegger S, Rom W, Steier P, Vycudilik W. 2000. ${ }^{14} \mathrm{C}$ dating with the bomb peak: an application to forensic medicine. Nuclear Instruments and Methods in Physics Research B 172(1-4):944-50.

Zheng Y, Anderson RF, Froelich PN, Beck W, McNichol AP, Guilderson T. 2002. Challenges in radiocarbon dating organic carbon in opal-rich marine sediments. Radiocarbon 44(1):123-36. 